Article

\title{
Tart Cherry Prevents Bone Loss through Inhibition of RANKL in TNF-Overexpressing Mice
}

\author{
Nicholas Moon ${ }^{1}$, Linda Effiong ${ }^{2}$, Lee Song ${ }^{2}$, Thomas R. Gardner ${ }^{2}$ and Do Y. Soung ${ }^{2,3, *}$ \\ 1 Department of Medicine, Case Western Reserve University, Cleveland, OH 44104, USA; Yxm273@case.edu \\ 2 Department of Orthopaedic Surgery, Columbia University, New York, NY 10032, USA; \\ lae2133@cumc.columbia.edu (L.E.); sl705@cumc.columbia.edu (L.S.); trg1@cumc.columbia.edu (T.R.G.) \\ 3 The Institutes of Food, CJ CheilJedang, CJ Blossom Park, 42, Gwanggyo-ro, Yeondong-gu, Suwon-si, \\ Gyeonggi-do 16495, Korea \\ * Correspondence: doyu.soung@cj.net; Tel.: +82-31-8099-1244
}

Received: 18 November 2018; Accepted: 24 December 2018; Published: 29 December 2018

check for updates

\begin{abstract}
Current drugs for the treatment of rheumatoid arthritis-associated bone loss come with concerns about their continued use. Thus, it is necessary to identify natural products with similar effects, but with fewer or no side effects. We determined whether tart cherry (TC) could be used as a supplement to prevent inflammation-mediated bone loss in tumor necrosis factor (TNF)-overexpressing transgenic (TG) mice. TG mice were assigned to a $0 \%, 5 \%$, or $10 \%$ TC diet, with a group receiving infliximab as a positive control. Age-matched wild-type (WT) littermates fed a $0 \%$ TC diet were used as a normal control. Mice were monitored by measurement of body weight. Bone health was evaluated via serum biomarkers, microcomputed tomography $(\mu \mathrm{CT})$, molecular assessments, and mechanical testing. TC prevented TNF-mediated weight loss, while it did not suppress elevated levels of interleukin (IL)-1 $\beta$ and IL-6. TC also protected bone structure from inflammation-induced bone loss with a reduced ratio of receptor activator of nuclear factor kappa-B ligand (RANKL)/osteoprotegerin (OPG) to a degree comparable to infliximab. Furthermore, unlike with infliximab, TC exhibited a moderate improvement in TNF-mediated decline in bone stiffness. Thus, TC could be used as a prophylactic regimen against future fragility fractures in the context of highly chronic inflammation.
\end{abstract}

Keywords: tart cherry; rheumatoid arthritis; TNF; osteoblast; osteoclast; RANKL; OPG; Runx2; bone mass; infliximab

\section{Introduction}

Rheumatoid arthritis (RA) is a chronic inflammatory disease resulting in joint destruction [1]. RA patients also exhibit low bone mass and increased risk of fracture compared to a representative population [2-7]. Bone loss and fragility in RA patients have been attributed to inactivity and use of corticosteroids for treating RA. However, inflammation has also been suggested as a risk factor [2,8-13].

Inflammatory cytokines, particularly tumor necrosis factor (TNF), are considered a contributing mediator in RA-associated bone loss. Specifically, TNF increases expression of the receptor activator of nuclear factor $\mathrm{KB}$ ligand (RANKL), which binds to RANK on the surface of pre-osteoclasts to generate mature osteoclasts, the bone resorbing cells [14]. On the other hand, TNF inhibits building of the bone matrix by decreasing differentiation of osteoblasts, along with downregulating gene expression of alkaline phosphatase (AP) and type I collagen (COL I) [14]. In fact, RA-associated bone loss is effectively treated by TNF-targeting antibodies such as infliximab, etanercept, or adalimumab $[2,8-11,15,16]$. Unfortunately, a significant side effect of these drugs is immunosuppression that leaves the patient greatly susceptible to infection [17]. Thus, developing alternative TNF-targeting strategies using an 
inflammation-modifying food that does not render the patient severely immunocompromised would be ideal for RA patients with osteoporosis.

One such candidate is tart cherry (TC, Prunus cerasus), a fruit rich in flavonoids such as flavonols (i.e., quercetin), hydroxycinnamic acids (i.e., neochlorogenic acid), flavan-3-ols (i.e., proanthocyanidins), and anthocyanidins [18,19]. TC with high content of these polyphenols has been reported to display antioxidant and anti-inflammatory properties [19-28]. For example, TC is capable of improving osteoarthritis by reducing C-reactive protein, a serum marker of inflammatory state, in a clinical trial [29]. Emerging data have also revealed that symptoms of RA are attenuated by treatments with individual polyphenol ingredients of TC including quercetin, proanthocyanidins, and antocyanidins in mouse models of RA using either collagen or adjuvant induction [30-32].

For these reasons, TC could be a promising non-pharmaceutical substitute for the drugs used in the prevention of bone loss in the setting of inflammation. Through this study, we evaluated the dose-dependent effects of TC diet on inflammation-mediated bone loss using TNF-overexpressing transgenic (TG) mice.

\section{Materials and Methods}

\subsection{Animals and Diet}

Female 3.5-4.5 week-old TG mice [33] were randomly assigned to three groups to feed on a diet of $0 \%, 5 \%$, or $10 \%$ TC for 4 weeks. TG mice have been extensively characterized to be proper animal models of rheumatoid arthritis-associated bone loss [34,35] as well as joint destruction [14,36,37]. As a control for standard TNF treatment [13], TG mice were fed a $0 \%$ TC diet and treated with an intraperitoneal dose of $10 \mathrm{mg} / \mathrm{kg}$ infliximab twice per week. Age-matched wild-type (WT) mice fed on a diet of $0 \%$ TC diet were used as an intact control group. All diets were formulated to be comparable in macronutrient and calorie content (Table 1) based on an AIN-93G diet for growth (Harlan, Indianapolis, IN, USA). These diets also took into account the nutrition facts of TC that were provided by the Cherry Market Institute. Diets were given to mice by pair-feeding to equal amounts of consumption as previously described [14]. Mice were allowed to freely access water during the entire experiment. All mice were housed at the Columbia University Medical Center animal facilities according to state and federal animal care guidelines (Institutional Animal Care and Use Committee number: AC-AAAI1502).

Table 1. Diet composition. TC: tart cherry.

\begin{tabular}{|c|c|c|c|c|}
\hline \multicolumn{2}{|c|}{ Ingredient } & \multirow{2}{*}{$\begin{array}{c}{ }^{1} \mathbf{0} \% \\
0\end{array}$} & \multirow{2}{*}{$\begin{array}{c}\begin{array}{c}\mathbf{5 \%} \\
\text { g/kg Diet }\end{array} \\
50\end{array}$} & \multirow{2}{*}{$\begin{array}{r}\mathbf{1 0 \%} \\
100\end{array}$} \\
\hline $\mathrm{TC}$ & & & & \\
\hline \multirow[t]{3}{*}{ Carbohydrates } & Cornstarch & 397.5 & 391.3 & 385.1 \\
\hline & Maltodextrin & 132 & 132 & 132 \\
\hline & Sucrose & 100.00 & 66.36 & 32.72 \\
\hline Proteins & Casein & 200 & 194.8 & 189.5 \\
\hline Fat & Soybean oil & 70.00 & 69.59 & 69.18 \\
\hline Fiber & Cellulose & 50.00 & 45.49 & 40.97 \\
\hline${ }^{2}$ Mineral mix & & 35 & 35 & 35 \\
\hline${ }^{3}$ Vitamin mix & & 10 & 10 & 10 \\
\hline Choline bitartrate & & 2.5 & 2.5 & 2.5 \\
\hline L-cystine & & 3 & 3 & 3 \\
\hline${ }^{4} \mathrm{TBHQ}$, antioxidants & & 0.014 & 0.014 & 0.014 \\
\hline \multicolumn{5}{|l|}{ Calculated nutrients } \\
\hline $\mathrm{Kcal} / \mathrm{g}$ & & 4 & 4 & 4 \\
\hline \multicolumn{5}{|c|}{ Macronutrients, $\%$ by weight } \\
\hline Protein & & 18 & 18 & 18 \\
\hline Carbohydrate & & 60 & 60 & 60 \\
\hline Fat & & 7 & 7 & 7 \\
\hline Sugar (sucrose $+\mathrm{TC}$ ) & & 13 & 13 & 13 \\
\hline
\end{tabular}

1 AIN-93G diet (Harlan, Indianapolis, IN, USA). ${ }^{2}$ AIN-93G-MX: $27.26 \mathrm{~g}$ of mineral mix and $7.74 \mathrm{~g}$ of sugar.

${ }^{3}$ AIN-93-VX: $0.25 \mathrm{~g}$ of vitamin mix and $9.75 \mathrm{~g}$ of sugar. ${ }^{4}$ TBHQ: Tertiary butylhydroquinone. 


\subsection{Inflammatory Cytokine Assay}

After a four-week treatment, mice were fasted for at least $6 \mathrm{~h}$ prior to euthanasia. Mice were then anesthetized using $100 \mu \mathrm{l}$ of intraperitoneal injection with $100 \mu \mathrm{g} / \mathrm{kg}$ of ketamine and $10 \mu \mathrm{g} / \mathrm{kg}$ of xylazine to obtain whole blood through cardiac puncture. Serum separated from blood was used to measure human TNF (hTNF), mouse interleukin-1 $\beta$ (mIL-1 $\beta$ ), and mIL-6 using an ELISA Kit (R\&D Systems, Minneapolis, MN, USA) as previously described [38,39].

\subsection{Microcomputed Tomography $(\mu \mathrm{CT})$}

Following sacrifice, left femoral bones were harvested, fixed with $10 \%$ neutral buffered formalin and then stored in phosphate buffered saline (PBS). Bone microcomputed tomography $(\mu \mathrm{CT})$ was performed with Scanco $\mu$ CT 35 (Scanco Medical, Brüttisellen, Switzerland) as previously described [14]. A 1.35-mm section of the distal part the left femur, starting $100 \mu \mathrm{m}$ from the growth plate, was used for trabecular bone analysis. A 1.4-mm section of the mid-diaphysis was used for analysis of cortical bone. A $6-\mu \mathrm{m}$ voxel size, $55 \mathrm{kVp}$, a $0.36^{\circ}$ rotation step $\left(180^{\circ}\right.$ angular range), and a $400-\mathrm{ms}$ exposure per view were used for the scans, which were performed in PBS. Scanco $\mu$ CT software (HP, DECwindows Motif 1.6, Scanco Medical, Brüttisellen, Switzerland) was used for 3D reconstruction and viewing of images. After 3D reconstruction, volumes were segmented using global thresholds of 300 and $560 \mathrm{mg} / \mathrm{c}$ for trabecular and cortical bone, respectively. Trabecular bone mass (Tb.BV/TV), number (Tb.N), thickness (Tb.Th), and space (Tb.Sp) were calculated for the trabecular bone. Cortical bone mass (BV/TV), thickness (Ct.Th), and porosity (Ct.Po) were also calculated for cortical bone.

\subsection{Molecular Assessments}

After $\mu \mathrm{CT}$, the left femurs were decalcified in 10\% EDTA for 14 days and embedded in paraffin. Each section of paraffin-embedded left femur containing the metaphyseal area was deparaffinized and lysed with RNeasy FFPE kit (Qiagen, Valencia, CA, USA) to isolate total RNA. Total RNA was reverse transcribed into cDNA using the High-Capacity RNA-to-cDNA ${ }^{\mathrm{TM}}$ Kit (Applied Biosystems, Foster City, CA, USA). The cDNA was then amplified with specific mouse primers (Table 2) in the presence of the PerfeCTa ${ }^{\circledR}$ Green SuperMix with Low ROX ${ }^{\mathrm{TM}}$ (QuantaBio, Beverly, MA, USA) via the QuantStudio 6 Flex (Applied Biosystems, Foster City, CA). Gene expression was normalized to that of glyceraldehyde 3-phosphate dehydrogenase (GAPDH).

Table 2. Mouse primer sequences. TNF: tumor necrosis factor; IL: interleukin; COL I: type I collagen; RANKL: receptor activator of nuclear factor kappa-B ligand; OPG: osteoprotegerin; TRAP: tartrate-resistant acid phosphatase; GAPDH: glyceraldehyde 3-phosphate dehydrogenase

\begin{tabular}{|c|c|c|}
\hline Target Name & Forward Primer $\left(5^{\prime}-3^{\prime}\right)$ & Reverse Primer $\left(5^{\prime}-3^{\prime}\right)$ \\
\hline TNF & CCCCAAAGGGATGAGAAGTT & GGTCTGGGCCATAGAACTGA \\
\hline IL-1 $\beta$ & ATGAAGGGCTGCTTCCAAA & GGACAGCCCAGGTCAAAG \\
\hline Runx2 & ССАССАСТСАСТАССАСАСG & CACTCTGGCTTTGGGAAGAG \\
\hline COL I & ACTGGTACATCAGCCCGAAC & AATCCATCGGTCATGCTCTC \\
\hline RANKL & CAGAAGGAACTGCAACACATTG & CTCCTGAGAAGCGCTGTG \\
\hline OPG & GTGTGGAATAGATGTCACCCT & AAGAAGGCCTCTTCACACAG \\
\hline TRAP & GATGACTTTGCCAGTCAGCA & AACTGCTTTTTGAGCCAGGA \\
\hline GAPDH & GGTCGGTGTGAACGGATTT & GACCAGGCGCCCAATAC \\
\hline
\end{tabular}

\subsection{Mechanical Testing}

The remaining right femoral bones of the mice after sacrifice were harvested and stored at $-80^{\circ} \mathrm{C}$. Bone quality and bone integrity were assessed by a three-point bending system (Instron Microtester 5848, Norwood, MA, USA) [40]. A test was performed in the anterior-posterior direction using a $100 \mathrm{~N}$ load cell (accuracy, $\pm 0.025 \mathrm{~N})$. A constant ramp displacement $(0.05 \mathrm{~mm} / \mathrm{s})$ was used to apply a load at the midpoint of the femur until failure. Failure load and stiffness were measured. The elastic 
moduli were also determined using Classical Beam Theory with dimensional values of the mouse femur. Their values were obtained from morphometric $\mu \mathrm{CT}$ data using a Skyscan $1272 \mu \mathrm{CT}$ system (Bruker, Manning Park, MA, USA).

\subsection{Statistical Analyses}

Values are presented as mean \pm SEM $(n=4-8)$. To assess the effects of treatment, a one-way analysis of variance (ANOVA) test comparing treatment groups via Prism Version 6.0f (GraphPad Software, Inc., La Jolla, CA, USA) was run. When ANOVA indicated any significant difference among the means $(p<0.05)$, Fisher's least significant difference test, without correcting for multiple comparison, was used to determine which means were significantly different $(p<0.05)$. For analysis of mechanical testing, we calculated the combined mean of the TG $+5 \%$ TC and TG $+10 \%$ TC groups due to the limited number of samples per group.

\section{Results}

\subsection{Although a High-Dose TC Diet Prevents TNF-Mediated Loss of Body Weight, It Does Not Suppress Elevated Proinflammatory Cytokines}

Since we performed pair-feeding to ensure an equal amount of consumption, all mice were fed around $2 \mathrm{~g}$ per day. Despite this, TG mice experienced significant reduction of body weight after a four-week treatment compared to WT mice (Figure 1). However, treatment of TG mice with either $10 \%$ TC or infliximab significantly attenuated TNF-induced loss of body weight.

We also measured protein levels of hTNF, mIL-1 $\beta$, and mIL-6 in sera obtained from the WT, TG, TG treated with 5\% TC, TG treated with 10\% TC, and TG treated with infliximab groups. We validated that serum levels of hTNF were absent in WT and highly elevated in TG mice regardless of treatment. Furthermore, we observed that TC did not alter TNF-mediated elevation of mIL-1 $\beta$ and mIL-6 levels, while infliximab significantly decreased serum levels to bring them down to that of WT. These data indicate that TC prevented TNF-induced loss of body weight without modulating serum proinflammatory cytokines.

Body Weight (g)

hTNF (pg/ml)

$\mathrm{mlL}-1 \beta(\mathrm{pg} / \mathrm{ml})$

mIL-6 (pg/ml)
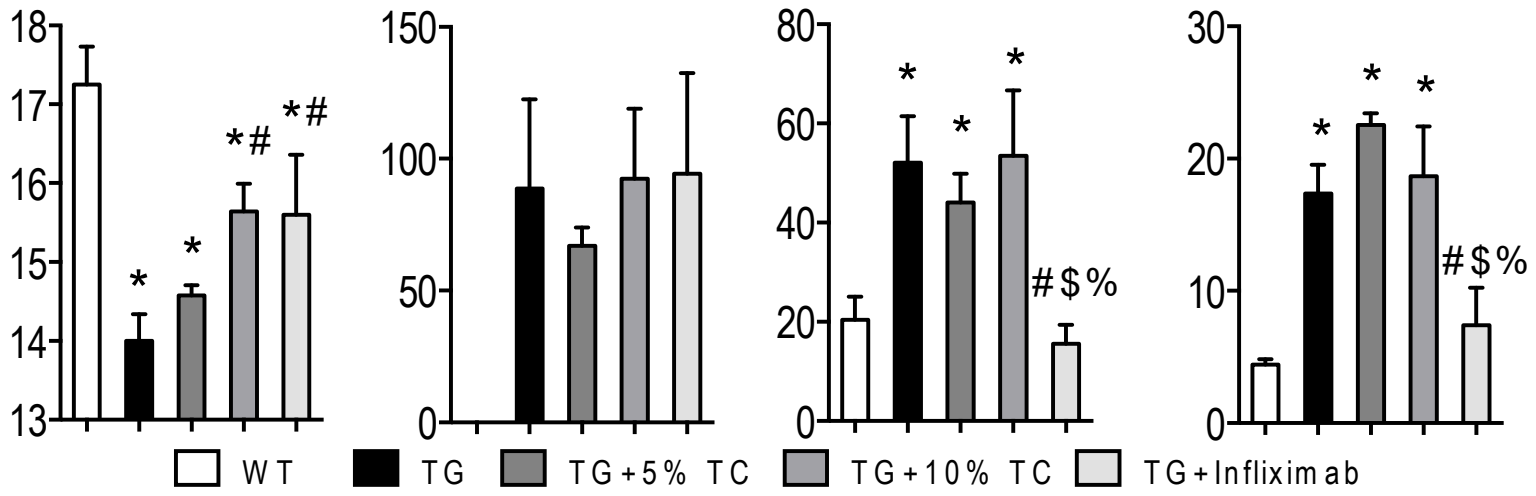

Figure 1. High-doses of TC recovered a TNF-mediated loss of body weight, but it did not suppress TNF-mediated elevation of proinflammatory cytokines in the blood. After 4 weeks of treatment, body weight was measured in wild-type (WT), transgenic (TG), TG with 5\% TC, TG with $10 \%$ TC, and TG with infliximab mice. Collected serum after sacrifice was also used to measure protein levels of human TNF (hTNF), mouse interleukin (mIL)- $1 \beta$, and mIL-6. Values are mean \pm SEM ( $n=4-8$ per group). *, $p<0.05$ vs. WT; $\#, p<0.05$ vs. TG; $\$, p<0.05$ vs. TG $+5 \%$ TC; $\%, p<0.05$ vs. TG $+10 \%$ TC. 


\subsection{TC Diet Dose-Dependently Protects Trabecular Bone from Inflammation-Induced Bone Destruction}

To examine the effects of TC on TNF-mediated alteration of microstructural morphology in trabecular bone (Figure 2), we performed $\mu \mathrm{CT}$ on femurs. In Figure 2A, TG showed a dramatic loss of metaphyseal trabecular bone mass compared to WT. However, TG fed on TC diet exhibited bone protective effects against TNF-mediated bone loss. The degree of trabecular bone loss caused by inflammation was also minimized by treatment with infliximab.

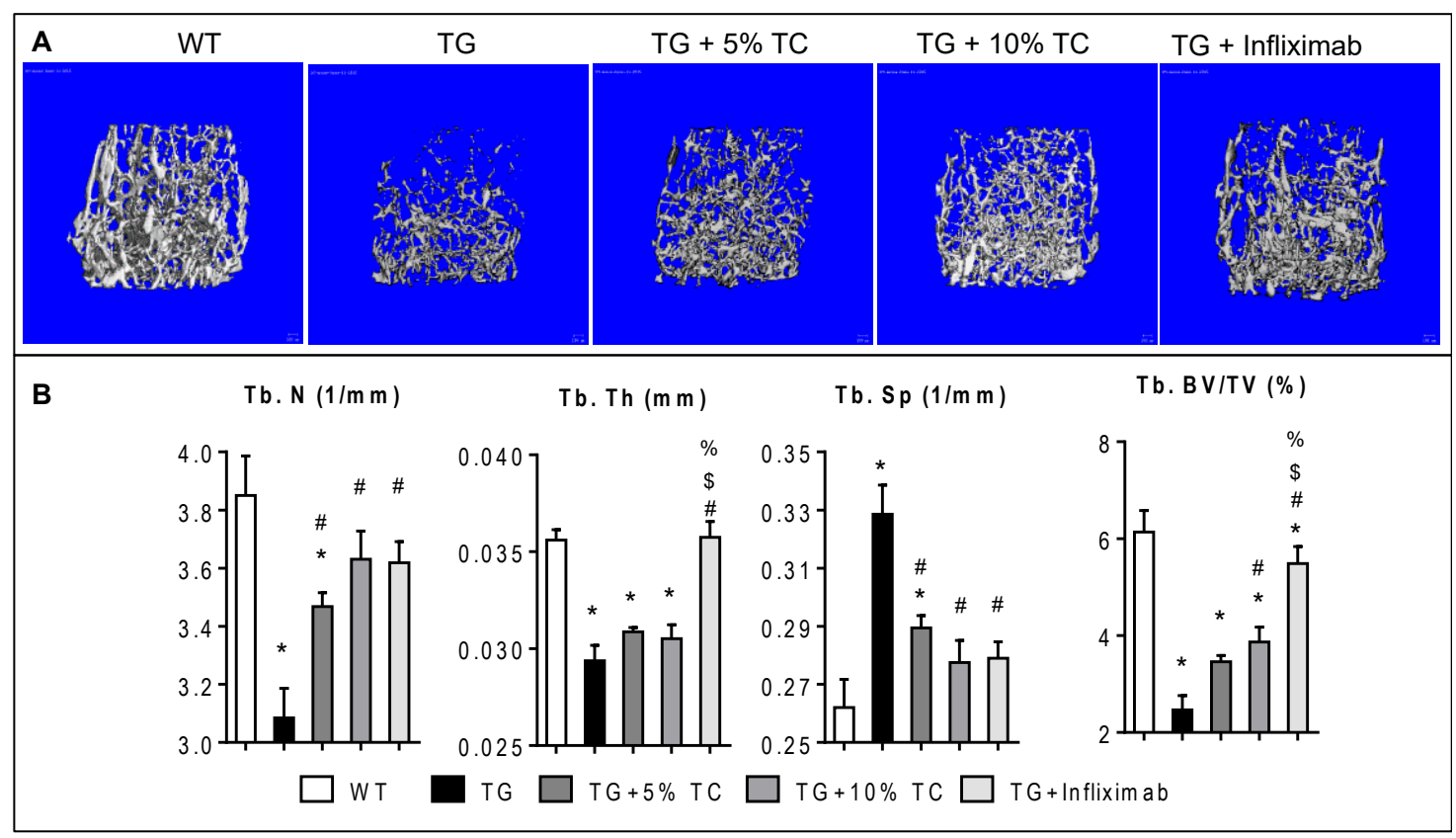

Figure 2. TC diet dose-dependently inhibited TNF-induced decline of trabecular bone mass. (A) Microcomputed tomography $(\mu \mathrm{CT})$ scans representing metaphyseal trabecular bone were taken from the femurs of WT, TG, TG $+5 \%$ TC, TG $+10 \% \mathrm{TC}$, and TG + infliximab mice. (B) Trabecular number (Tb.N), thickness (Tb.Th), space (Tb.Sp), and bone mass (Tb.BV/TV) were quantified using $\mu \mathrm{CT}$ analysis. Values are mean $\pm \operatorname{SEM}\left(n=4-8\right.$ per group). ${ }^{*}, p<0.05$ vs. WT; $\#, p<0.05$ vs. TG; $\$, p<0.05$ vs. TG $+5 \%$ TC; $\%, p<0.05$ vs. TG $+10 \%$ TC.

TG mice showed significant decreases in both Tb.N and Tb.Th by $20 \%$ and $18 \%$, respectively compared to WT mice. TNF-mediated reduction of Tb.N was significantly recovered by treatment with either TC (5\% and $10 \%$ ) or infliximab by $6-10 \%$ or $6 \%$, respectively. On the other hand, only treatment with infliximab significantly restored TNF-induced narrowing of Tb.Th to the levels of WT. Additionally, TG mice showed a significantly higher Tb.Sp, at 1.25-fold over WT. Similar to treatment with infliximab, both doses of TC diet significantly inhibited a TNF-induced increase in Tb.Sp by $12 \%$ and $16 \%$, respectively. Overall, TG mice displayed $40 \%$ of Tb.BV/TV compared to WT, while TG mice treated with either TC diet or infliximab exhibited $56-63 \%$ or $89 \%$, respectively, compared to WT. Both imaging and quantitative data indicate that treatment with TC inhibits loss of trabecular bone mass through recovery from significant TNF-mediated reduction of the number and increase of space in the trabecular structure.

\subsection{TC Diet Prevents a TNF-Mediated Reduction of Cortical Thickness and Increase of Cortical Porosity}

We also assessed microstructural properties of cortical bone in the diaphyseal area of femurs (Figure 3). TG mice exhibited much thinner cortical bone compared to WT (Figure 3A). However, TG mice treated with either TC diet or infliximab showed an intermediate thickness of cortical bone, between that of WT and TG. 


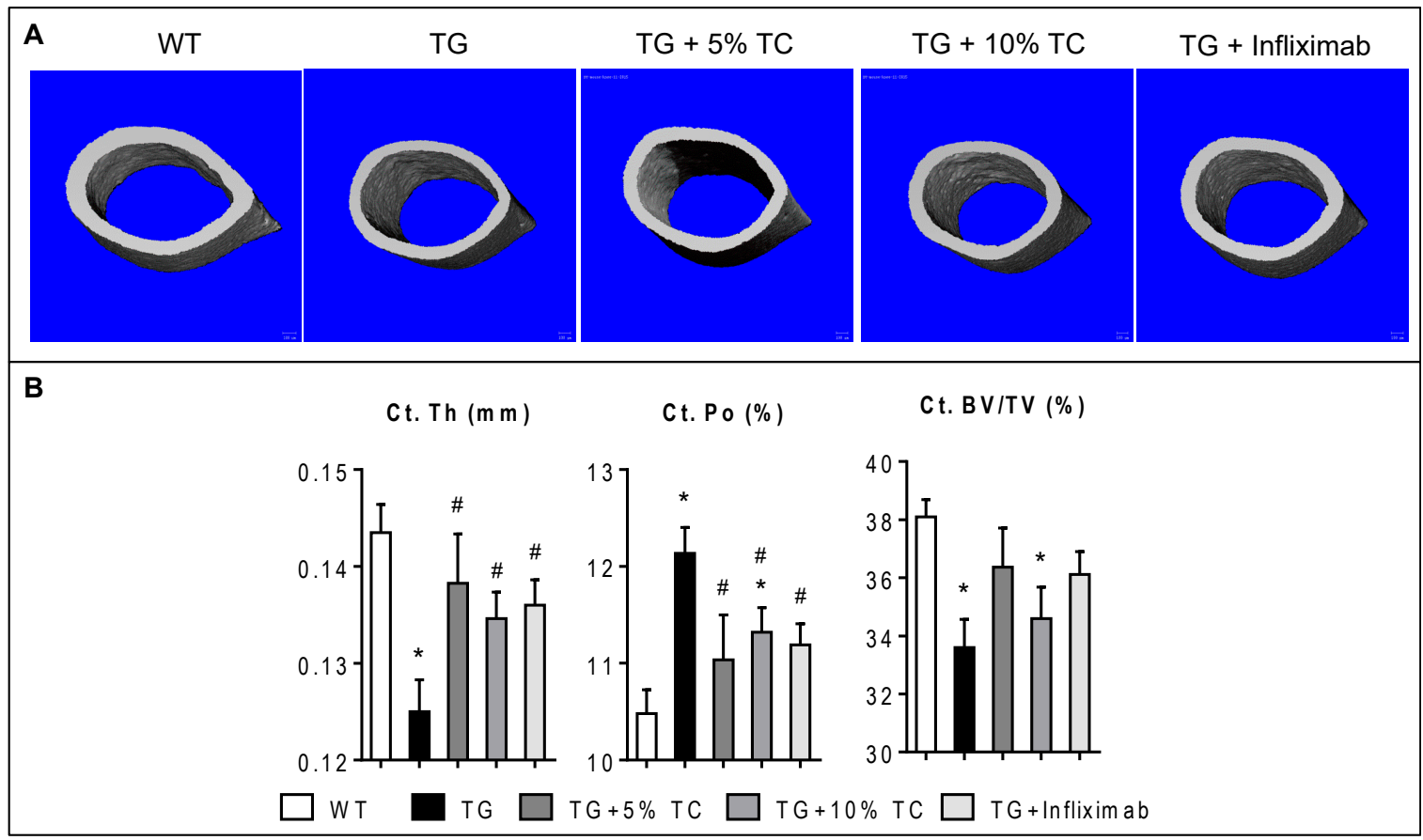

Figure 3. TC diet improved modification of cortical bone structure by inflammation. (A) Microcomputed tomography $(\mu \mathrm{CT})$ scans representing sections of cortical bone were taken for femurs of $\mathrm{WT}, \mathrm{TG}, \mathrm{TG}+5 \%$ $\mathrm{TC}$, TG $+10 \% \mathrm{TC}$, and TG+infliximab mice. (B) Cortical thickness (Ct.Th), porosity (Ct.Po), and bone mass $(\mathrm{Ct} . \mathrm{BV} / \mathrm{TV})$ were quantified using $\mu \mathrm{CT}$ analysis. Values are mean $\pm \operatorname{SEM}(n=4-8$ per group $) .{ }^{*}, p<0.05$ vs. WT; \#, $p<0.05$ vs. TG.

Significant reduction of Ct.Th by 13\% and induction of Ct.Po by 16\% in TG were observed compared to WT (Figure 3B). However, treatment with either a $5 \%$ or $10 \%$ TC diet significantly prevented TNF-mediated reduction of Ct.Th, by $4 \%$ and $6 \%$, respectively. Furthermore, the TC diet significantly decreased TNF-induced Ct.Po compared to the control diet. Similar effects were also shown in TG mice treated with infliximab. Finally, significant inflammation-mediated reduction of cortical bone mass $(12 \%)$ was modestly recovered by treatment with either $5 \%$ TC or infliximab. These data indicate that TC diet modestly improved the modification of cortical bone structure caused by inflammation.

\subsection{TC Modulates Gene Expressions Altered by TNF during Bone Destruction}

To determine the role of TC in TNF-mediated gene profiling under the condition of bone destruction, we measured the transcript levels of (1) the proinflammatory cytokines TNF and IL-1 $\beta$, (2) the osteoblast markers runt-related transcription factor 2 (Runx2) and COL I, and (3) the osteoclast-associated genes tartrate-resistant acid phosphatase (TRAP), RANKL, and osteoprotegrin (OPG) (Figure 4).

mRNA levels of TNF and $I L-1 \beta$ were highly expressed in TG compared to WT. While these elevated expressions were significantly further increased or maintained by treatment with TC diet, they were modestly and significantly decreased by treatment with infliximab. The transcript levels of Runx2 were significantly and highly expressed in TG treated with TC compared to WT. Diet with $10 \%$ TC also significantly increased transcript levels of Runx2 compared to TG group. However, its expression in TG mice treated with infliximab was brought down to levels of the WT and TG groups. Nevertheless, the expression of COL I was not affected by the status of TG and treatments. 
TNF

Runx2

COL I
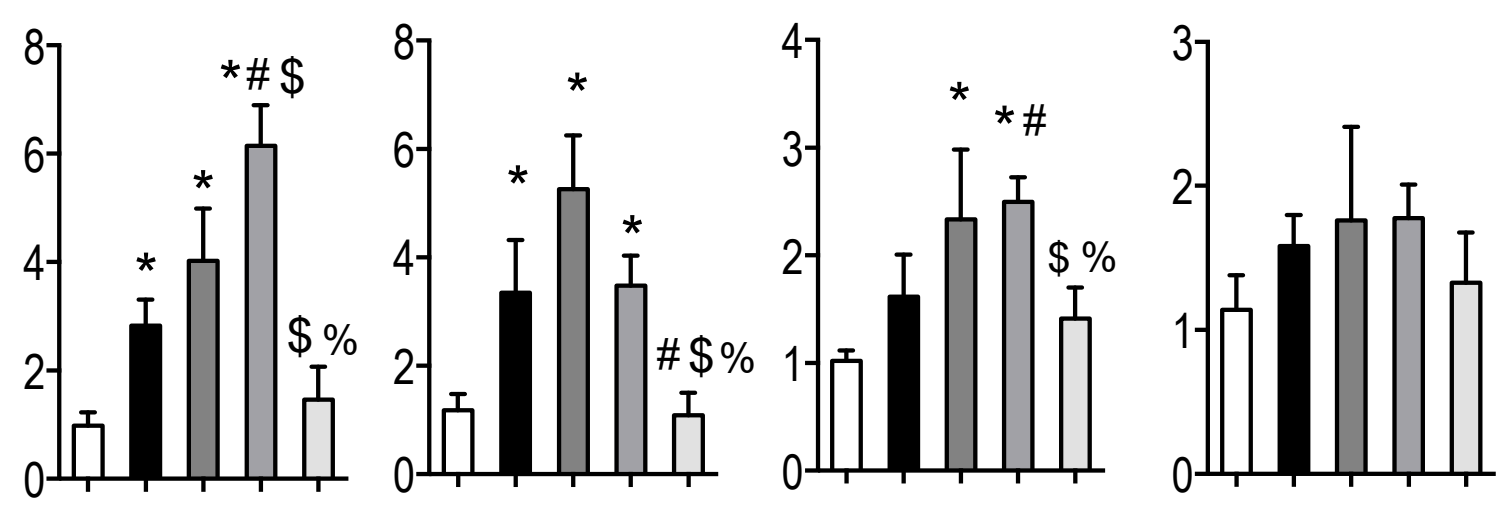

RANKL

OPG

RANKL/OPG

\section{TRAP}
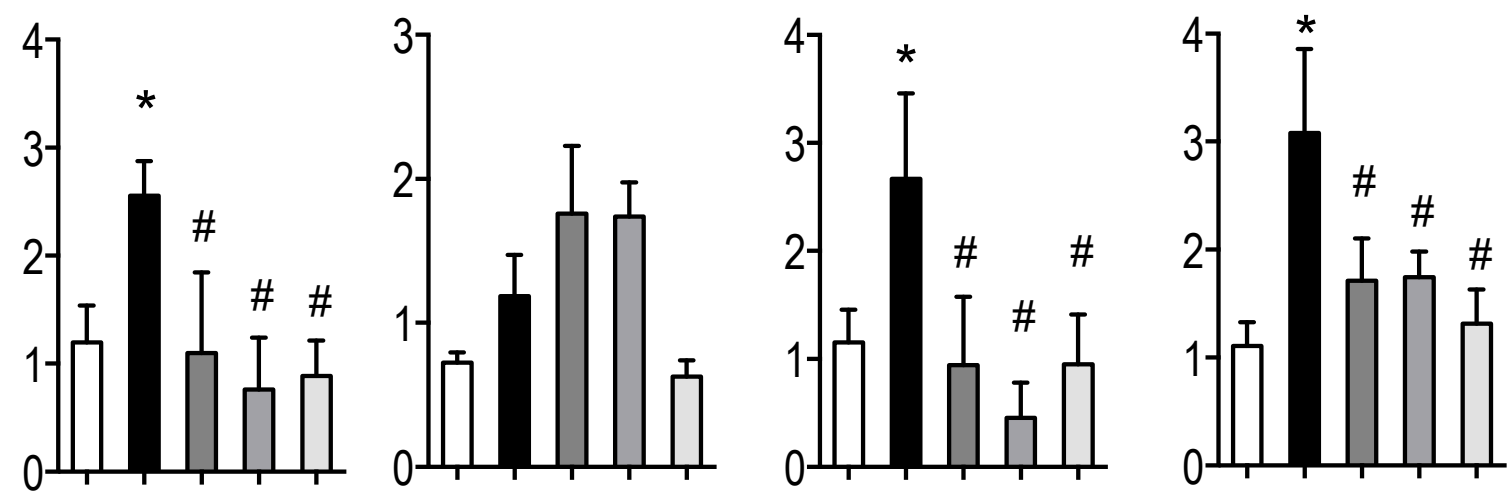

W T

TG

$\mathrm{TG}+5 \% \mathrm{TC}$

$T G+10 \%$ TC

$T G+\operatorname{Inflixim} a b$

Figure 4. TC downregulated gene expressions of RANKL and TRAP. Total RNA was extracted from histological sections of metaphyseal area in each femur of WT, TG, TG $+5 \%$ TC, TG $+10 \%$ TC, and TG + infliximab mice. cDNA converted from total RNA was applied to measure relative transcript levels of TNF, IL-1 $\beta$, Runx2, COL I, RANKL, and TRAP that were normalized to GAPDH using RT-PCR. Values are means $(n=4-8) \pm$ SEM. ${ }^{*}, p<0.05$ vs. WT; $\#, p<0.05$ vs. TG; $\$, p<0.05$ vs. TG $+5 \%$ TC; $\%, p<0.05$ vs. TG $+10 \%$ TC.

Increased transcript levels of RANKL in TG mice were significantly reduced by either TC or infliximab treatment without influencing that of OPG. Following a similar pattern to RANKL, highly expressed TNF-mediated levels of TRAP were significantly decreased by treatment with either TC or infliximab. The data indicate that TC diet regulates genes associated with osteoclasts and osteoblasts with an uncoupling system to have beneficial effects on bone mass.

\subsection{TC Diet Modestly Improves TNF-Mediated Reduction of Mechanical Strength}

To determine the effects of TC on TNF-induced damage of the structural and material properties, we performed a three-point bending experiment to measure failure load, stiffness, and modulus (Figure 5). Because of the limited number of bone, we combined the two groups (TG $+5 \%$ and TG + $10 \%$ ) for these analyses. 
Failure Load (N)

Stiffness (N/mm)

Modulus (Gpa)
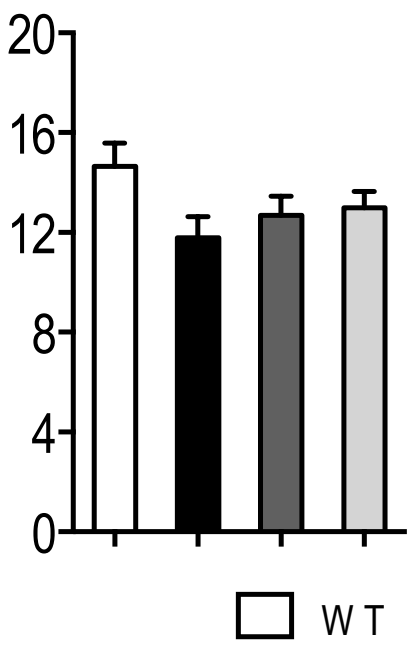

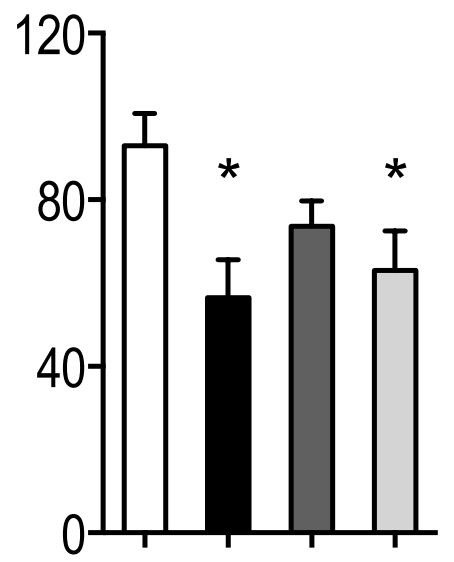

TG

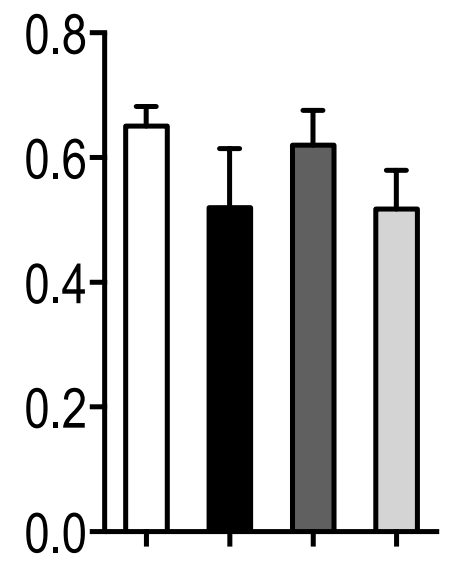

$T G+\ln$ flixim $a b$

Figure 5. TC exhibited a modest improvement of bone stiffness devastated by TNF overexpression. Right femurs were placed on the machine with a three-point bending mechanical system to measure and determine failure load, stiffness, and modulus. The $5 \%$ and $10 \%$ TC mice were combined for these parameters to make a total of four groups: WT, TG, TG + TC, and TG + infliximab. Values are means $(n=4-9) \pm$ SEM. $^{*}, p<0.05$ vs WT.

No differences were found across all groups for failure load or modulus. However, there was a significant reduction in stiffness in TG mice compared to WT by $39 \%$. While treatment with TC diet was modestly able to prevent this reduction in stiffness, treatment with infliximab was not. This indicates that the increased bone mass mediated by treatment with TC correlates to an improvement in mechanical strength.

\section{Discussion}

The purpose of this study is to examine the effects of TC on inflammation-mediated bone loss and fragility using TNF-overexpressing mice. We demonstrated that TC protected bone mass and strength from the state of inflammation.

Expectedly, infliximab prevented TNF-mediated bone loss and inhibited the progression of systemic inflammation. This observation has also been demonstrated in RA patients treated with TNF-targeting antibodies including infliximab by showing a great efficacy in improving bone mass as well as alleviating RA symptoms such as joint pain $[2,8-11,15,16]$. On the other hand, a TC diet demonstrated bone protective properties against TNF-mediated bone destruction in both trabecular and cortical bones without altering the state of inflammation. Similar results were observed in TNF overexpressing mice with treatment of denosumab (DMAB), which was recently developed in the form of an antibody against RANKL. That is, DMAB prevented bone loss without reducing TNF-mediated overproduction of inflammatory cytokines [34]. DMAB has also been tested in RA patients with osteoporosis and was shown to improve bone mass [41-43]. Since previous studies have found TC to lower serum protein levels of TNF as well as other proinflammatory cytokines in both human [44] and rat subjects [45], TC is likely to have a modest anti-inflammatory effect in the setting of a mild inflammatory condition. However, our data suggests that under the state of chronically high systemic overexpression of inflammatory mediators, TC regulates TNF-mediated loss of bone mass at the local rather than systemic level.

We found that TC downregulated expression of RANKL and TRAP, which are indicative of osteoclast formation. These effects of whole TC were also displayed by the individual bioactive compounds found in TC. For example, kaempferol abrogated TNF-induced nuclear factor- $\mathrm{kB}$ 
(NFKB) activation, leading to decreased formation of osteoclasts [46]. Proanthocyanidin prevented RANKL-induced osteoclast formation and activity through repression of nuclear factor of activated T-cells (cytoplasmic 1 (NFATc1)) [47]. Cyanidin also inhibits RANKL-induced osteoclast formation in preosteoclasts (RAW264.7 cells) [48]. Furthermore, we previously demonstrated that neochlorogenic acid reduced formation of osteoclasts via repression of osteoclast-specific gene expressions including TRAP and cathepsin K (CatK) stimulated by TNF in primary mouse bone marrow cells [14]. Thus, the molecular mechanism behind the effect of TC on inflammation-mediated bone loss may be working via the inhibition of osteoclast-associated gene expressions.

Bone mass is determined by the overall balance of functions between osteoclasts and osteoblasts. TC downregulates gene expression of markers of osteoclasts while maintaining those of osteoblasts through an uncoupling scheme under the inflammatory condition. A similar pattern was previously observed for an inhibitor of CatK that was capable of improving bone mass by maintaining bone formation while inhibiting bone resorption [39]. Strontum ranelate, a drug used in the treatment of postmenopausal osteoporosis, also increased bone formation but deceased bone resorption $[49,50]$. Based on our data, TC uncouples osteoblasts and osteoclasts, leading to maintenance of bone mass under the inflammatory condition.

The increased bone mass in TG mice treated with TC confers modestly improved bone strength. Interestingly, the significant improvements to bone morphology by infliximab are not associated with a similar enhancement of bone strength. Our data agreed with a population-based cohort study demonstrating that RA subjects treated with infliximab showed an increased bone mineral density, but not an improvement to bone strength compared to patients treated with methotrexate [51]. In spite of the enhanced bone mass, bisphosphonates, anti-bone resorptive drugs used in the treatment of osteoporosis, [12,52-54] also exhibit undesirable outcomes in bone strength and quality. For example, the continuous usage of bisphosphonates for more than 5 years was associated with increased atypical fractures at the sites of the subtrochanteric and femoral shaft in a cohort of women aged 68 years or older [55]. Furthermore, osteoporotic patients who took bisphosphates (alendronate) for several years even displayed delayed or deficient fracture healing [56]. This vulnerability in bone quality caused by bisphosphonates could be due to an accumulation of old bone matrix secondary to a decreased degree of both bone formation and resorption. Thus, TC might improve bone quality and fracture healing via maintaining bone formation by overcoming these restrictions of anti-bone resorptive drugs.

\section{Conclusions}

An intake of TC that enhanced bone mass through uncoupling of osteoclasts and osteoblasts conferred bone strength. This quality might offer the usage of a safe long-term dietary supplement for the prevention of future fragility fractures in states of high chronic inflammation.

Author Contributions: Conceptualization, D.Y.S.; Methodology, T.R.G. and D.Y.S.; Software, L.E.; Validation, T.R.G., L.S. and D.Y.S.; Formal Analysis, N.M. and L.E.; Writing-Original Draft Preparation, N.M. and L.E.; Writing-Review \& Editing, L.S. \& T.R.G. \& D.Y.S.; Visualization, N.M. and L.E.; Supervision, T.R.G. and L.S.; Funding Acquisition, D.Y.S.

Funding: This research was funded by Cherry Market Institute.

Acknowledgments: We thank George Kollias (Biomedical Sciences Research Center "Alexander Fleming", Vari, Greece) for kind permission to use transgenic mice (TG) carrying the human TNF gene (Tg197).

Conflicts of Interest: The authors declare no conflict of interest. 


\section{References}

1. Myasoedova, E.; Crowson, C.S.; Kremers, H.M.; Therneau, T.M.; Gabriel, S.E. Is the incidence of rheumatoid arthritis rising? Results from Olmsted County, Minnesota, 1955-2007. Arthritis Rheum. 2010, 62, 1576-1582. [CrossRef] [PubMed]

2. Haugeberg, G.; Uhlig, T.; Falch, J.A.; Halse, J.I.; Kvien, T.K. Bone mineral density and frequency of osteoporosis in female patients with rheumatoid arthritis: Results from 394 patients in the Oslo County Rheumatoid Arthritis register. Arthritis Rheum. 2000, 43, 522-530. [CrossRef]

3. Rossini, M.; Bagnato, G.; Frediani, B.; Iagnocco, A.; G, L.A.M.; Minisola, G.; Caminiti, M.; Varenna, M.; Adami, S. Relationship of focal erosions, bone mineral density, and parathyroid hormone in rheumatoid arthritis. J. Rheumatol. 2011, 38, 997-1002. [CrossRef] [PubMed]

4. Forsblad-d'Elia, H.; Carlsten, H. Hormone replacement therapy in postmenopausal women with rheumatoid arthritis stabilises bone mineral density by digital X-ray radiogrammetry in a randomised controlled trial. Ann. Rheum. Dis. 2011, 70, 1167-1168. [CrossRef] [PubMed]

5. Wright, N.C.; Lisse, J.R.; Walitt, B.T.; Eaton, C.B.; Chen, Z.; Women's Health Initiative, I. Arthritis increases the risk for fractures-Results from the Women's Health Initiative. J. Rheumatol. 2011, 38, 1680-1688. [CrossRef] [PubMed]

6. van Staa, T.P.; Geusens, P.; Bijlsma, J.W.; Leufkens, H.G.; Cooper, C. Clinical assessment of the long-term risk of fracture in patients with rheumatoid arthritis. Arthritis Rheum. 2006, 54, 3104-3112. [CrossRef] [PubMed]

7. Vis, M.; Haavardsholm, E.A.; Boyesen, P.; Haugeberg, G.; Uhlig, T.; Hoff, M.; Woolf, A.; Dijkmans, B.; Lems, W.; Kvien, T.K. High incidence of vertebral and non-vertebral fractures in the OSTRA cohort study: A 5-year follow-up study in postmenopausal women with rheumatoid arthritis. Osteoporos. Int. 2011, 22, 2413-2419. [CrossRef]

8. Wijbrandts, C.A.; Klaasen, R.; Dijkgraaf, M.G.; Gerlag, D.M.; van Eck-Smit, B.L.; Tak, P.P. Bone mineral density in rheumatoid arthritis patients 1 year after adalimumab therapy: Arrest of bone loss. Ann. Rheum. Dis. 2009, 68, 373-376. [CrossRef] [PubMed]

9. Marotte, H.; Pallot-Prades, B.; Grange, L.; Gaudin, P.; Alexandre, C.; Miossec, P. A 1-year case-control study in patients with rheumatoid arthritis indicates prevention of loss of bone mineral density in both responders and nonresponders to infliximab. Arthritis Res. 2007, 9, R61. [CrossRef]

10. Hoff, M.; Kvien, T.K.; Kalvesten, J.; Elden, A.; Kavanaugh, A.; Haugeberg, G. Adalimumab reduces hand bone loss in rheumatoid arthritis independent of clinical response: Subanalysis of the PREMIER study. BMC Musculoskelet. Disord. 2011, 12, 54. [CrossRef]

11. Krieckaert, C.L.; Nurmohamed, M.T.; Wolbink, G.; Lems, W.F. Changes in bone mineral density during long-term treatment with adalimumab in patients with rheumatoid arthritis: A cohort study. Rheumatology 2013, 52, 547-553. [CrossRef] [PubMed]

12. Saidenberg-Kermanach, N.; Corrado, A.; Lemeiter, D.; deVernejoul, M.C.; Boissier, M.C.; Cohen-Solal, M.E. TNF-alpha antibodies and osteoprotegerin decrease systemic bone loss associated with inflammation through distinct mechanisms in collagen-induced arthritis. Bone 2004, 35, 1200-1207. [CrossRef] [PubMed]

13. Redlich, K.; Gortz, B.; Hayer, S.; Zwerina, J.; Doerr, N.; Kostenuik, P.; Bergmeister, H.; Kollias, G.; Steiner, G.; Smolen, J.S.; et al. Repair of local bone erosions and reversal of systemic bone loss upon therapy with anti-tumor necrosis factor in combination with osteoprotegerin or parathyroid hormone in tumor necrosis factor-mediated arthritis. Am. J. Pathol. 2004, 164, 543-555. [CrossRef]

14. Mirza, F.; Lorenzo, J.; Drissi, H.; Lee, F.Y.; Soung, D.Y. Dried plum alleviates symptoms of inflammatory arthritis in TNF transgenic mice. J. Nutr. Biochem. 2018, 52, 54-61. [CrossRef] [PubMed]

15. Engvall, I.L.; Tengstrand, B.; Brismar, K.; Hafstrom, I. Infliximab therapy increases body fat mass in early rheumatoid arthritis independently of changes in disease activity and levels of leptin and adiponectin: A randomised study over 21 months. Arthritis Res. 2010, 12, R197. [CrossRef] [PubMed]

16. Serelis, J.; Kontogianni, M.D.; Katsiougiannis, S.; Bletsa, M.; Tektonidou, M.G.; Skopouli, F.N. Effect of anti-TNF treatment on body composition and serum adiponectin levels of women with rheumatoid arthritis. Clin. Rheumatol. 2008, 27, 795-797. [CrossRef] [PubMed]

17. Saag, K.G.; Teng, G.G.; Patkar, N.M.; Anuntiyo, J.; Finney, C.; Curtis, J.R.; Paulus, H.E.; Mudano, A.; Pisu, M.; Elkins-Melton, M.; et al. American College of Rheumatology 2008 recommendations for the use of 
nonbiologic and biologic disease-modifying antirheumatic drugs in rheumatoid arthritis. Arthritis Rheum. 2008, 59, 762-784. [CrossRef] [PubMed]

18. Bonerz, D.; Wurth, K.; Dietrich, H.; Will, F. Analytical characterization and the impact of ageing on anthocyanin composition and degradation in juices from five sour cherry cultivars. Eur. Food Res. Technol. 2007, 224, 355-364. [CrossRef]

19. Kirakosyan, A.; Seymour, E.M.; Llanes, D.E.U.; Kaufman, P.B.; Bolling, S.F. Chemical profile and antioxidant capacities of tart cherry products. Food Chem. 2009, 115, 20-25. [CrossRef]

20. Bell, P.G.; Walshe, I.H.; Davison, G.W.; Stevenson, E.; Howatson, G. Montmorency cherries reduce the oxidative stress and inflammatory responses to repeated days high-intensity stochastic cycling. Nutrients 2014, 6, 829-843. [CrossRef] [PubMed]

21. Ou, B.; Bosak, K.N.; Brickner, P.R.; Iezzoni, D.G.; Seymour, E.M. Processed tart cherry products-comparative phytochemical content, in vitro antioxidant capacity and in vitro anti-inflammatory activity. J. Food Sci. 2012, 77, H105-H112. [CrossRef] [PubMed]

22. Zhou, Z.; Nair, M.G.; Claycombe, K.J. Synergistic inhibition of interleukin-6 production in adipose stem cells by tart cherry anthocyanins and atorvastatin. Phytomedicine 2012, 19, 878-881. [CrossRef] [PubMed]

23. Traustadottir, T.; Davies, S.S.; Stock, A.A.; Su, Y.; Heward, C.B.; Roberts, L.J., 2nd; Harman, S.M. Tart cherry juice decreases oxidative stress in healthy older men and women. J. Nutr. 2009, 139, 1896-1900. [CrossRef] [PubMed]

24. Haidari, F., Jr.; Mohammad Shahi, M.; Keshavarz, S.A.; Rashidi, M.R. Inhibitory Effects of Tart Cherry (Prunus cerasus) Juice on Xanthine Oxidoreductase Activity and its Hypouricemic and Antioxidant Effects on Rats. Malays. J. Nutr. 2009, 15, 53-64. [PubMed]

25. Tall, J.M.; Seeram, N.P.; Zhao, C.; Nair, M.G.; Meyer, R.A.; Raja, S.N. Tart cherry anthocyanins suppress inflammation-induced pain behavior in rat. Behav. Brain Res. 2004, 153, 181-188. [CrossRef] [PubMed]

26. Seeram, N.P.; Momin, R.A.; Nair, M.G.; Bourquin, L.D. Cyclooxygenase inhibitory and antioxidant cyanidin glycosides in cherries and berries. Phytomedicine 2001, 8, 362-369. [CrossRef]

27. Wang, H.; Nair, M.G.; Strasburg, G.M.; Booren, A.M.; Gray, J.I. Antioxidant polyphenols from tart cherries (Prunus cerasus). J. Agric. Food Chem. 1999, 47, 840-844. [CrossRef]

28. Wang, H.; Nair, M.G.; Strasburg, G.M.; Booren, A.M.; Gray, J.I. Novel antioxidant compounds from tart cherries (Prunus cerasus). J. Nat. Prod. 1999, 62, 86-88. [CrossRef]

29. Schumacher, H.R.; Pullman-Mooar, S.; Gupta, S.R.; Dinnella, J.E.; Kim, R.; McHugh, M.P. Randomized double-blind crossover study of the efficacy of a tart cherry juice blend in treatment of osteoarthritis (OA) of the knee. Osteoarthr. Cartil. 2013, 21, 1035-1041. [CrossRef]

30. Cho, M.L.; Heo, Y.J.; Park, M.K.; Oh, H.J.; Park, J.S.; Woo, Y.J.; Ju, J.H.; Park, S.H.; Kim, H.Y.; Min, J.K. Grape seed proanthocyanidin extract (GSPE) attenuates collagen-induced arthritis. Immunol. Lett. 2009, 124, 102-110. [CrossRef]

31. He, Y.H.; Xiao, C.; Wang, Y.S.; Zhao, L.H.; Zhao, H.Y.; Tong, Y.; Zhou, J.; Jia, H.W.; Lu, C.; Li, X.M.; et al. Antioxidant and anti-inflammatory effects of cyanidin from cherries on rat adjuvant-induced arthritis. Zhongguo Zhong Yao Za Zhi 2005, 30, 1602-1605. [PubMed]

32. Choi, E.J.; Bae, S.C.; Yu, R.; Youn, J.; Sung, M.K. Dietary vitamin E and quercetin modulate inflammatory responses of collagen-induced arthritis in mice. J. Med. Food 2009, 12, 770-775. [CrossRef] [PubMed]

33. Keffer, J.; Probert, L.; Cazlaris, H.; Georgopoulos, S.; Kaslaris, E.; Kioussis, D.; Kollias, G. Transgenic mice expressing human tumour necrosis factor: A predictive genetic model of arthritis. EMBO J. 1991, 10, 4025-4031. [CrossRef]

34. Schett, G.; Redlich, K.; Hayer, S.; Zwerina, J.; Bolon, B.; Dunstan, C.; Gortz, B.; Schulz, A.; Bergmeister, H.; Kollias, G.; et al. Osteoprotegerin protects against generalized bone loss in tumor necrosis factor-transgenic mice. Arthritis Rheum. 2003, 48, 2042-2051. [CrossRef] [PubMed]

35. Bohm, C.; Derer, A.; Axmann, R.; Hillienhoff, U.; Zaiss, M.M.; Luther, J.; Zech, C.; Stock, M.; Scholtysek, C.; Engelke, K.; et al. RSK2 protects mice against TNF-induced bone loss. J. Cell. Sci. 2012, 125, 2160-2171. [CrossRef] [PubMed]

36. Zwerina, J.; Redlich, K.; Polzer, K.; Joosten, L.; Kronke, G.; Distler, J.; Hess, A.; Pundt, N.; Pap, T.; Hoffmann, O.; et al. TNF-induced structural joint damage is mediated by IL-1. Proc. Natl. Acad. Sci. USA 2007, 104, 11742-11747. [CrossRef] 
37. Stamer, D.K.; Nizami, S.A.; Lee, F.Y.; Soung D, Y. Whole grape alleviates inflammatory arthritis through inhibition of tumor necrosis factor. J. Funct. Foods 2017, 35, 458-565. [CrossRef]

38. Soung do, Y.; Kalinowski, J.; Baniwal, S.K.; Jacome-Galarza, C.E.; Frenkel, B.; Lorenzo, J.; Drissi, H. Runx1-mediated regulation of osteoclast differentiation and function. Mol. Endocrinol. 2014, 28, 546-553. [CrossRef]

39. Soung do, Y.; Gentile, M.A.; Duong le, T.; Drissi, H. Effects of pharmacological inhibition of cathepsin K on fracture repair in mice. Bone 2013, 55, 248-255. [CrossRef]

40. Tascau, L.; Gardner, T.; Anan, H.; Yongpravat, C.; Cardozo, C.P.; Bauman, W.A.; Lee, F.Y.; Oh, D.S.; Tawfeek, H.A. Activation of Protein Kinase A in Mature Osteoblasts Promotes a Major Bone Anabolic Response. Endocrinology 2016, 157, 112-126. [CrossRef]

41. Nakamura, Y.; Suzuki, T.; Kato, H. Denosumab significantly improves bone mineral density with or without bisphosphonate pre-treatment in osteoporosis with rheumatoid arthritis: Denosumab improves bone mineral density in osteoporosis with rheumatoid arthritis. Arch. Osteoporos. 2017, 12, 80. [CrossRef] [PubMed]

42. Mochizuki, T.; Yano, K.; Ikari, K.; Kawakami, K.; Hiroshima, R.; Koenuma, N.; Ishibashi, M.; Momohara, S. Effects of denosumab treatment on bone mineral density and joint destruction in patients with rheumatoid arthritis. J. Bone Miner. MeTable 2018, 36, 431-438. [CrossRef] [PubMed]

43. Ebina, K.; Hirao, M.; Hashimoto, J.; Hagihara, K.; Kashii, M.; Kitaguchi, K.; Matsuoka, H.; Iwahashi, T.; Chijimatsu, R.; Yoshikawa, H. Assessment of the effects of switching oral bisphosphonates to denosumab or daily teriparatide in patients with rheumatoid arthritis. J. Bone Miner. MeTable 2018, 36, 478-487. [CrossRef] [PubMed]

44. Martin, K.R.; Burrell, L. 100\% Tart cherry juice reduces pro-inflammatory biomarkers in overweight and obese subjects. FASEB J. 2010, 24, 15.

45. Seymour, E.M.; Lewis, S.K.; Urcuyo-Llanes, D.E.; Tanone, II.; Kirakosyan, A.; Kaufman, P.B.; Bolling, S.F. Regular tart cherry intake alters abdominal adiposity, adipose gene transcription, and inflammation in obesity-prone rats fed a high fat diet. J. Med. Food 2009, 12, 935-942. [CrossRef] [PubMed]

46. Pang, J.L.; Ricupero, D.A.; Huang, S.; Fatma, N.; Singh, D.P.; Romero, J.R.; Chattopadhyay, N. Differential activity of kaempferol and quercetin in attenuating tumor necrosis factor receptor family signaling in bone cells. Biochem. Pharmacol. 2006, 71, 818-826. [CrossRef] [PubMed]

47. Park, J.S.; Park, M.K.; Oh, H.J.; Woo, Y.J.; Lim, M.A.; Lee, J.H.; Ju, J.H.; Jung, Y.O.; Lee, Z.H.; Park, S.H.; et al. Grape-seed proanthocyanidin extract as suppressors of bone destruction in inflammatory autoimmune arthritis. PLoS ONE 2012, 7, e51377. [CrossRef] [PubMed]

48. Moriwaki, S.; Suzuki, K.; Muramatsu, M.; Nomura, A.; Inoue, F.; Into, T.; Yoshiko, Y.; Niida, S. Delphinidin, one of the major anthocyanidins, prevents bone loss through the inhibition of excessive osteoclastogenesis in osteoporosis model mice. PLoS ONE 2014, 9, e97177. [CrossRef] [PubMed]

49. Atkins, G.J.; Welldon, K.J.; Halbout, P.; Findlay, D.M. Strontium ranelate treatment of human primary osteoblasts promotes an osteocyte-like phenotype while eliciting an osteoprotegerin response. Osteoporos. Int. 2009, 20, 653-664. [CrossRef] [PubMed]

50. Brennan, T.C.; Rybchyn, M.S.; Green, W.; Atwa, S.; Conigrave, A.D.; Mason, R.S. Osteoblasts play key roles in the mechanisms of action of strontium ranelate. Br. J. Pharmacol. 2009, 157, 1291-1300. [CrossRef] [PubMed]

51. Kim, S.Y.; Schneeweiss, S.; Liu, J.; Solomon, D.H. Effects of disease-modifying antirheumatic drugs on nonvertebral fracture risk in rheumatoid arthritis: A population-based cohort study. J. Bone Miner. Res. 2012, 27, 789-796. [CrossRef] [PubMed]

52. Hsu, H.; Lacey, D.L.; Dunstan, C.R.; Solovyev, I.; Colombero, A.; Timms, E.; Tan, H.L.; Elliott, G.; Kelley, M.J.; Sarosi, I.; et al. Tumor necrosis factor receptor family member RANK mediates osteoclast differentiation and activation induced by osteoprotegerin ligand. Proc. Natl. Acad. Sci. USA 1999, 96, 3540-3545. [CrossRef] [PubMed]

53. McClung, M.R.; Lewiecki, E.M.; Cohen, S.B.; Bolognese, M.A.; Woodson, G.C.; Moffett, A.H.; Peacock, M.; Miller, P.D.; Lederman, S.N.; Chesnut, C.H.; et al. Denosumab in postmenopausal women with low bone mineral density. N. Engl. J. Med. 2006, 354, 821-831. [CrossRef]

54. Yamane, H.; Sakai, A.; Mori, T.; Tanaka, S.; Moridera, K.; Nakamura, T. The anabolic action of intermittent PTH in combination with cathepsin $\mathrm{K}$ inhibitor or alendronate differs depending on the remodeling status in bone in ovariectomized mice. Bone 2009, 44, 1055-1062. [CrossRef] 
55. Park-Wyllie, L.Y.; Mamdani, M.M.; Juurlink, D.N.; Hawker, G.A.; Gunraj, N.; Austin, P.C.; Whelan, D.B.; Weiler, P.J.; Laupacis, A. Bisphosphonate use and the risk of subtrochanteric or femoral shaft fractures in older women. JAMA 2011, 305, 783-789. [CrossRef] [PubMed]

56. Odvina, C.V.; Zerwekh, J.E.; Rao, D.S.; Maalouf, N.; Gottschalk, F.A.; Pak, C.Y. Severely suppressed bone turnover: A potential complication of alendronate therapy. J. Clin. Endocrinol. MeTable 2005, 90, 1294-1301. [CrossRef]

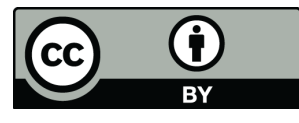

(C) 2018 by the authors. Licensee MDPI, Basel, Switzerland. This article is an open access article distributed under the terms and conditions of the Creative Commons Attribution (CC BY) license (http://creativecommons.org/licenses/by/4.0/). 